\title{
COMMENTARY: THE RISKS OF RISING GLOBAL INDEBTEDNESS
}

\author{
Barry Naisbitt*
}

\section{Introduction}

Financial stability reports published by central banks and commentaries by international agencies such as the International Monetary Fund (IMF) and Bank for International Settlements (BIS) frequently highlight the high level of debt (private sector or public sector or both) as an important risk consideration for the outlook for both continued economic growth and for financial stability. While for every borrower there is also a lender, it is thought to be the debt side of the balance sheet that carries more risk in the economy. A standard view of debt is that it enables the smoothing of consumption and investment over time. But agents with debt can then become exposed to shocks to income and interest rates when repaying debt and to the lack of availability of funds when they need to re-finance debt as it matures or to issue new debt. The various analyses of the financial crisis reveal how some of these channels operated (or failed to operate) and views about the importance of the growth of debt before the crisis are likely being reflected in the continuing focus on debt. This commentary argues that high levels of debt are one of the main sources of vulnerability in the world economy and examines some common themes that have emerged across economies since the crisis.

\section{Debt since the Great Recession}

The advanced economies as a whole ${ }^{1}$ at the end of 2017 had total debt outstanding 2 of $\$ 123$ trillion (276 per cent of GDP), a new record level and some $\$ 30$ trillion higher than when they entered the financial crisis. Given the different sizes of economies, it is most helpful to consider the level of debt relative to the level of GDP. As figure 1 illustrates, many of the major advanced economies now have higher debt-to-GDP ratios than a decade ago.

The story of the evolution of total debt in the past decade for China and other emerging economies ${ }^{3}$ is rather
Figure I. Selected advanced economies, total debt-toGDP ratios (\%)

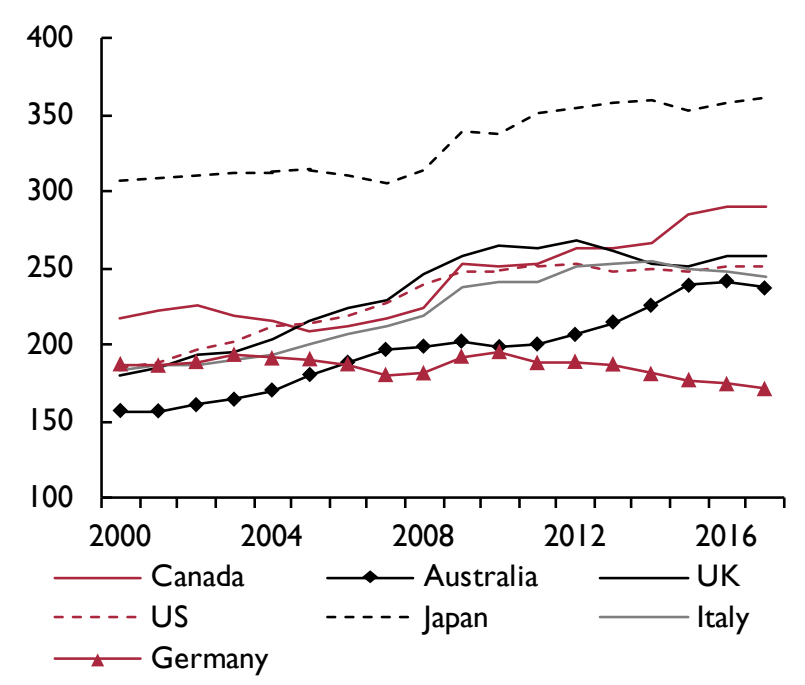

Source: BIS total credit statistics, May 2018.

different from that of the advanced economies. The trends in total debt in both absolute terms (in US dollars) and as a share of GDP are shown in figures 2 and 3. At $\$ 54$ trillion in 2017, total debt is $\$ 38$ trillion higher than a decade ago, a proportionately larger expansion than in the advanced economies. While emerging economies' (with the exception of China) debt-to-GDP ratios are lower than for the advanced economies, their debt has risen rapidly.

While the emerging economies show quite a range of experience, rising debt has been a characteristic of the past decade and, as figure 2 and table 1 show, it is the increase in debt raised by non-financial companies that has been a major driver, particularly in China. 
Figure 2. Emerging economies, total debt (\$tr)(a)

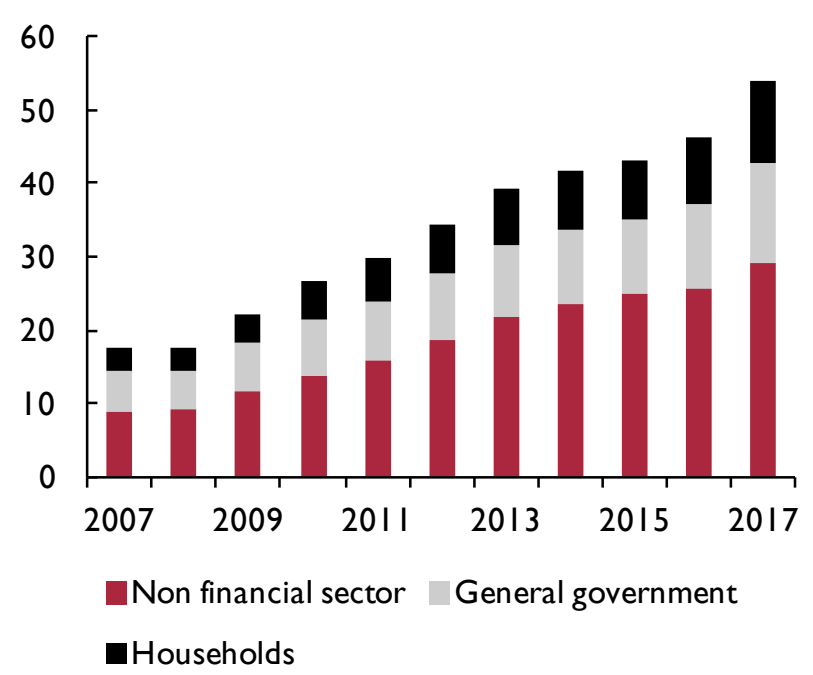

Source: BIS total credit statistics.

Note: (a) As defined by BIS. See Dembiermont et al. (20I3).

Figure 3. Emerging economies, total debt-to-GDP ratios (\%)

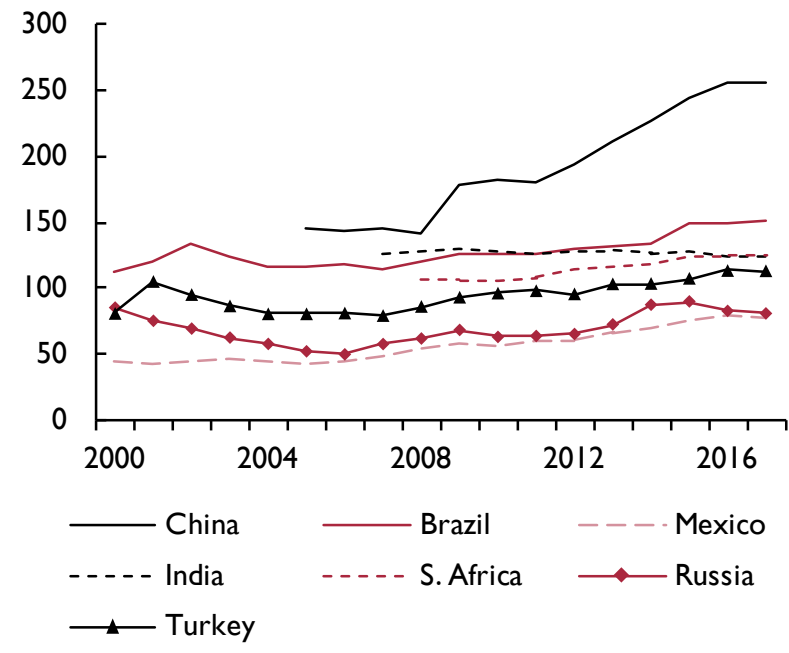

Source: BIS total credit statistics.

Table 1 presents a detailed breakdown of the change in both total debt and in its contributors for a number of key economies. Perhaps the defining feature is that the main source of the expansion of debt over the past decade has been different for advanced economies than emerging economies. For the advanced economies, it is the widespread increase in public sector debt that stands out. There have been some increases in household and corporate debt, but they are not as substantial. The rise in debt in emerging economies, on the other hand, has come from a widespread rise in the debt of nonfinancial companies. While many emerging economies have seen increases in household and government debt, the increases for corporate borrowing are more marked than in the advanced economies, excepting perhaps France.

One consequence of these developments is that if there is a 'debt problem', it is possible that it would take different forms in the two groups of countries.

\section{Trends in public sector debt}

Much of the economic debate on debt is about government debt. Table 1 shows levels of debt issued by governments, households and non-financial corporations as a share of nominal GDP for some advanced and emerging economies. Government debt ratios in advanced economies have risen substantially since the Great Recession, reflecting the direct effects of the recession on government revenues and expenditures and the policy responses to the crisis. In several of the advanced economies, the rise in government debt was a clear economic and political concern. Perhaps the remarkable feature of the financial crisis was that "none of the usual suspects - the 'serial defaulters' of previous sovereign debt crises, namely, Brazil, Indonesia, Mexico, and Thailand - ran into trouble" (Cohen and Valadier, 2011).

\begin{tabular}{|c|c|c|c|c|c|c|}
\hline & \multicolumn{2}{|c|}{$\begin{array}{c}\text { General } \\
\text { government }\end{array}$} & \multicolumn{2}{|c|}{ Households } & \multicolumn{2}{|c|}{$\begin{array}{c}\text { Non-financial } \\
\text { companies }\end{array}$} \\
\hline & 2007 & 2017 & 2007 & 2017 & 2007 & 2017 \\
\hline \multicolumn{7}{|c|}{ Advanced Economies } \\
\hline Canada & 49.1 & 71.6 & 78.7 & 100.2 & 85.9 & 114.0 \\
\hline Australia & 8.2 & 37.5 & 108.1 & 121.7 & 80.4 & 75.2 \\
\hline US & 57.7 & 97.0 & 97.9 & 78.7 & 69.7 & 73.5 \\
\hline UK & 41.9 & 87.9 & 92.8 & 86.7 & 94.7 & 83.8 \\
\hline France & 64.4 & 96.9 & 46.5 & 58.7 & 103.9 & 133.8 \\
\hline Italy & 99.8 & 131.7 & 38.2 & 40.9 & 74.6 & 71.2 \\
\hline Germany & 63.6 & 64.0 & 61.1 & 52.9 & 55.9 & 54.5 \\
\hline Japan & 144.7 & 200.5 & 58.4 & 57.4 & 103.0 & 103.4 \\
\hline \multicolumn{7}{|c|}{ Emerging Economies } \\
\hline Brazil & 63.1 & 83.1 & 15.4 & 24.7 & 35.1 & 43.9 \\
\hline Mexico & 20.5 & 35.5 & 13.5 & I6.1 & 14.8 & 26.8 \\
\hline India & 73.7 & 68.7 & 10.7 & 10.9 & 42.3 & 44.7 \\
\hline South Africa & 28.5 & 54.8 & 43.9 & 33.1 & 35.0 & 38.0 \\
\hline Russia & 8.3 & 15.5 & 10.5 & 16.2 & 39.0 & 49.3 \\
\hline Turkey & 39.8 & 28.4 & 11.3 & 17.4 & 29.9 & 67.5 \\
\hline China & 29.3 & 47.0 & 18.8 & 48.4 & 96.8 & 160.3 \\
\hline
\end{tabular}

Source: BIS total credit statistics.

Note: The shading in the table shows where debt-to-GDP ratios are higher than in the preceding period. 
When debt-to-GDP ratios are elevated a natural concern is whether they might hit a level at which there is an adverse effect on overall economic performance. This issue has been the centre of considerable debate. Reinhart and Rogoff (2010) attracted much academic and media attention with their claim that government debt above a 90 per cent ratio to GDP leads to notably slower economic growth. 4

This 90 per cent ratio finding has been hotly contested by other economists (Herndon et al, 2013, and De Long, 2013) (including the identification of an Excel error in the original spreadsheet) and, with some stabilisation in debt-to-GDP ratios in the past two years, it seems to have less resonance now. Recent research has moved focus to consider the issue of maximum sustainable debt which, rather than focussing on a single ratio as a key indicator, relates sustainable debt positively to the average rate of GDP growth (Collard et al., 2015).

A key reason for concern about the rise in debt is that what may seem affordable at a given time in terms of debt as a share of GDP, the scale of debt repayments or the ability to re-finance or rollover debt, may not be so in the future. For advanced economies and most emerging economies, the interest rates that their governments are now paying on debt are at historically low levels. The combination of the long downward drift in global real interest rates (Bean et al., 2015; Holston et al., 2016), the monetary policy responses in the Great Recession and beyond when policy interest rates were lowered to and held at or close to the zero lower bound, and the policies of quantitative easing in the US, UK, Japan and the Euro Area have contributed to declines in longerterm market rates for government debt. Lower rates reduce the direct financing cost and can be seen as a form of financial repression.

While continued low rates help to reduce the financing cost for governments, they do not take away a concern that if rates were to rise by more than anticipated there would be adverse effects on governments' financial positions and governments' resolve to maintain financial discipline could weaken, possibly leading to the re-emergence of inflation as a means of reducing debt ratios.

\section{Trends in private sector debt}

For financial stability concerns within economies it is the growth of private sector debt that has emerged as more of a concern recently. The housing market was at the epicentre of the financial crisis in the US (Mian and Sufi, 2014). While US households' borrowing has been increasing in recent years, household debt relative to income is still lower than before the crisis. This is not, however, the case everywhere. Where household sector debt-to-GDP ratios remain elevated, a concern for financial stability is to understand the extent to which higher ratios are more likely to be supported by current and expected ultra-low interest rates than by more positive expectations of future income growth.

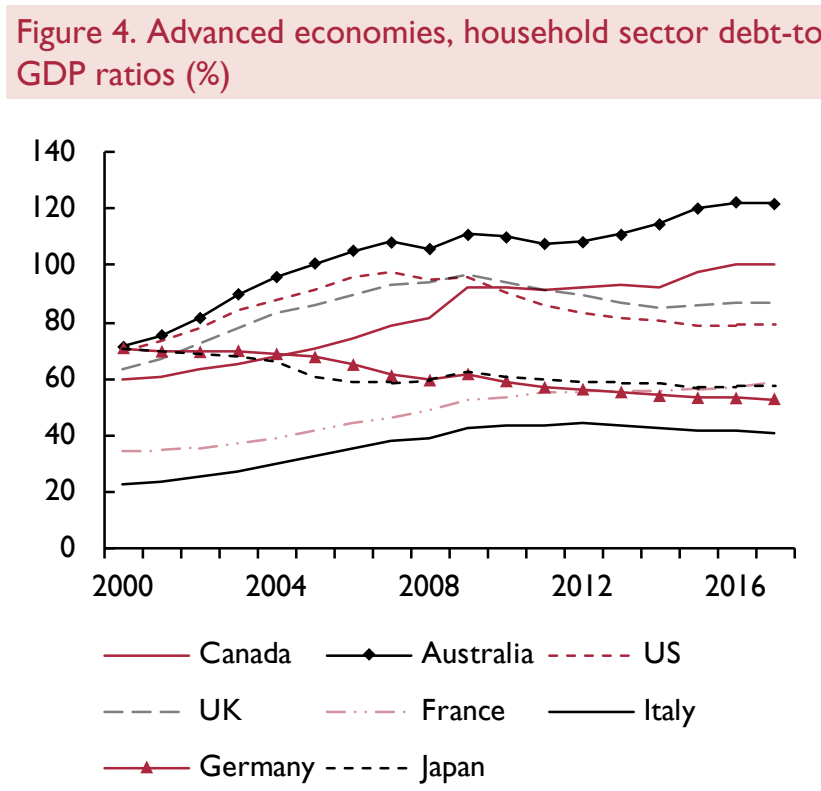

Source: BIS total credit statistics.

Figure 5. Household debt servicing costs (\% of income)

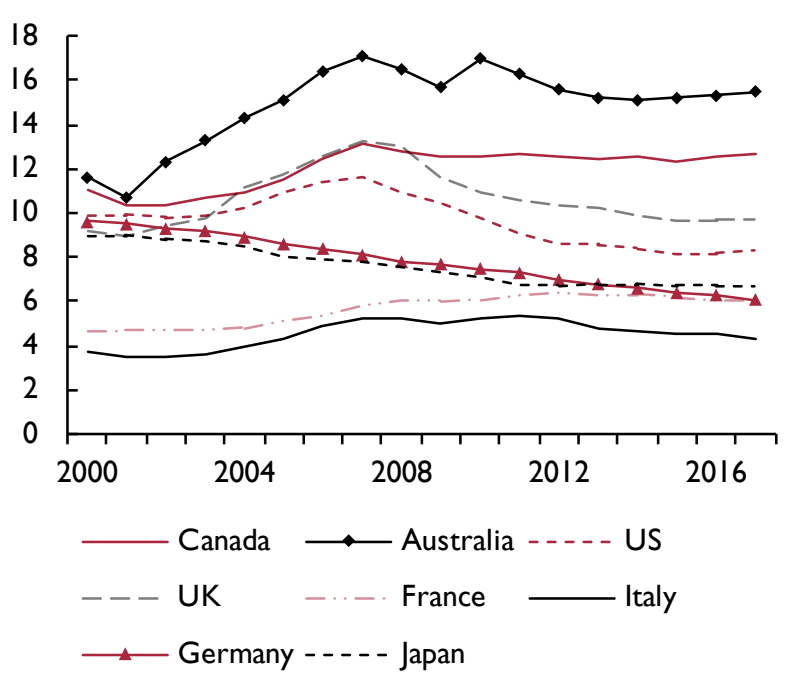

Source: BIS total credit statistics. 
Figure 6. Real house prices (index 2005 $=100$ )

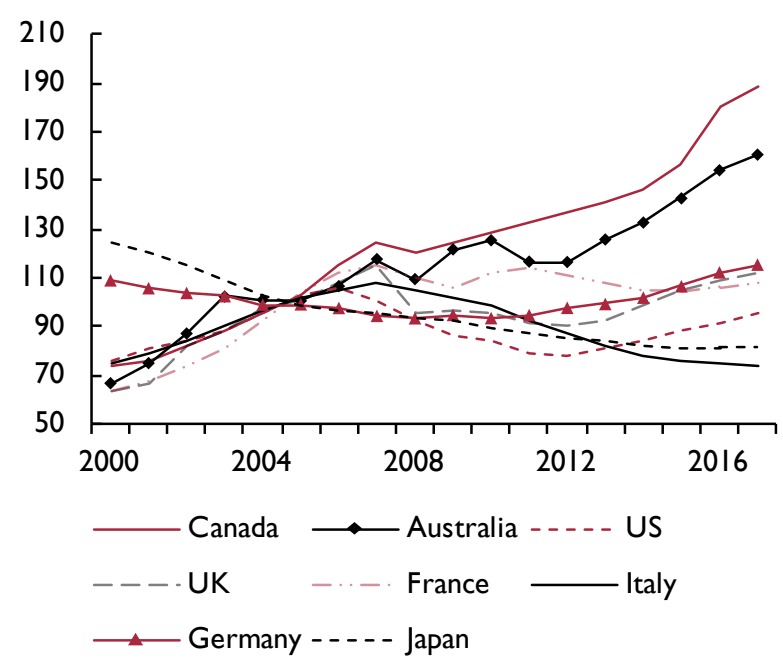

Source: Dallas Federal Reserve Bank.

Canada and Australia have seen continued rises in mortgage debt and new peaks in real house prices. In these countries the housing sector remains a potential source of vulnerability. 5 The principal difficulty for policymakers here is determining whether high debt and rising real house prices are sustainable (and could rise even further) or whether they represent incipient 'bubble' conditions which might burst if the economies faced shocks such as unexpected increases in interest rates or downturns in economic growth, with consequent rises in unemployment. The economic policy debate has spent much time discussing the wisdom and efficacy of whether policy should try to burst what is seen as a developing asset price bubble or should focus on the over-riding economic policy objectives (see, e.g., Mishkin, 2011). The consensus view has been that identifying 'bubbles' is too imprecise a science to drive monetary policy actions. Increasing additional vigilance from a macro-prudential policy perspective is being used to bring into play some additional policy options (such as restricting mortgage loan to income limits) to effect an adjustment.

While household sector debt attracts a great deal of press commentary for the advanced economies, recent developments in the non-financial corporate sector have now started to attract more comment (Naisbitt, 2018). Private sector corporate debt has been rising much faster in emerging markets than in advanced economies in recent years. Corporate sector debt in China has increased particularly notably and has been commented upon as a possible cause for concern (IMF, 2015).
Figure 7. Credit to private non-financial sector (share of GDP (\%)

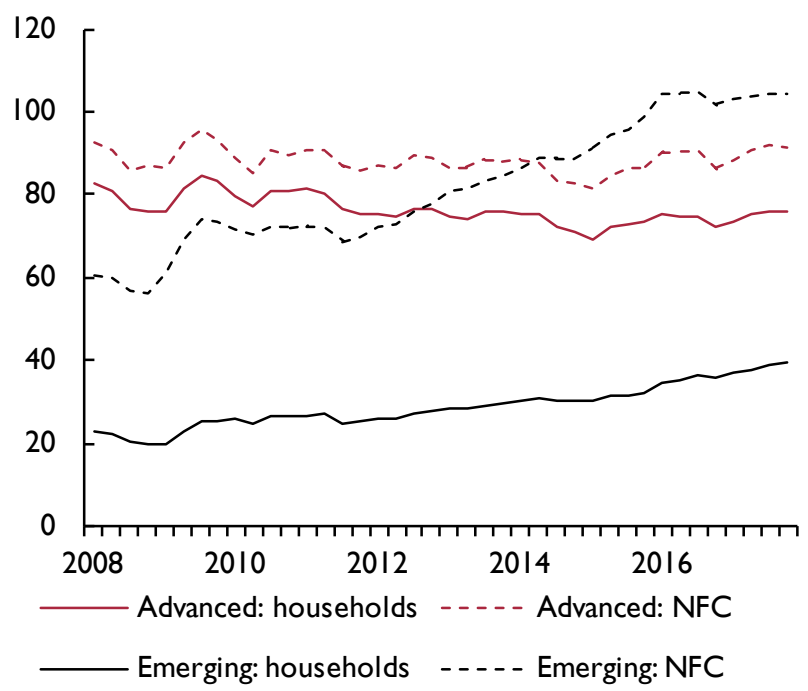

Source: BIS total credit statistics.

For corporates in emerging economies the rapid rise in debt has increased the rollover risk, with many corporates having moved from bank to bond financing. McKinsey (2018) notes that "global corporate default rates are already above their long-term average, and the prospect of rising interest rates may put more corporate bond borrowers at higher risk" and calculates that in response to a 2 percentage point rise in interest rates, the share of corporate bonds at higher risk of default in China could rise to 43 per cent. Estimates are that around $\$ 2$ trillion of corporate bonds will mature annually over the next five years. An additional complication is that many of the debts by companies in emerging markets may have been issued in foreign currency (most commonly in US dollars) as global financialisation has increased, raising an exposure to rising US domestic interest rates via global financial markets and, perhaps more importantly, also exposure to currency movements relative to the US dollar. If the revenues to pay debt service payments are being raised in domestic currency, the value of that currency depreciating against the US dollar raises the domestic cost of the foreign currency repayment. In Turkey over 25 per cent of government and corporate debt is dollar denominated and Mexico and Brazil are approaching 20 per cent. While China has a low percentage of US dollar denominated debt (less than 10 per cent), much of the market concern has focussed on Chinese corporates, where debt growth has been faster than in other emerging market economies. One more unknown factor is the extent to which spillover effects from one 
economy could lead to problems in other economies, with contagion emerging as a risk.

\section{Potential concerns about debt}

Drawing attention to the developments in indebtedness in both public and private sectors is a pre-requisite to considering where the potential risks from this increase may lie. Setting aside the obvious risk of another recession coming from some undefined shock and leading to widespread defaults due to the scale and pattern of debt, at least two other possible concerns arise in current circumstances.

The first derives from the extended period of ultra-low policy interest rates and the resulting financial repression during which debt has increased. If the rise in private sector debt has been primarily a 'bringing forward' response to low interest rates and improved economic prospects of economies 'transitioning' to higher debt levels as a consequence of increased prosperity, then an anticipation of a gradual increase in policy interest rates could be expected to be met by a reduction in the pace of growth of debt rather than a rise in defaults. But if a substantial portion of the recent rise in debt has been purely a short-term response to lower interest rates, perhaps a consequence of the 'paradox of policy' (King, 2012), and if borrowers have not allowed for a 'margin of safety' then, if interest rates were to rise (perhaps even gradually), defaults could build more quickly than anticipated. The BIS figures show that debt-service ratios for companies in emerging markets have been more volatile than in advanced economies over the past decade and have risen in China and Turkey. So any sudden increase could place an additional challenge on monetary policy authorities; the potential vulnerability created by higher indebtedness is likely to act as one factor constraining rapid rises in (and much higher) interest rates. The other side of this is that if a substantial shock occurs, rates still at ultra-low levels leave little ammunition for central banks to ameliorate the effects of such a shock, which, in turn, could put pressure on the public finances.

A second concern may appear at a global level, in much the same way as the South East Asia Crisis in 1997-8 spread out from that region to the wider sphere (Aghevli, 1999). The interconnectedness of economies, especially at a financial level, has increased, in much the same way that, for example, China has now become more embedded in international trade networks (BoE, 2018). External sovereign debts have been shown to play a role in broadening global financial cycles. The need for refinancing and rolling-over of public and private corporate sector debt could arise at a more substantial level just at the time that the price of new borrowing has risen substantially. The public and private sector nature of the growth of debt over the past decade could well mean that, as the Greek debt crisis demonstrated, providing an effective 'bail-out' could be a very difficult problem, requiring appropriate institutional structures to deal with any restructuring of debt. At a global level, at elevated debt levels, any sudden crisis may be turn out to be a test of the robustness of the international financial system as much as of the individual countries that may be directly affected by the adverse shocks.

\section{Monitoring and mitigating risks}

Following the Great Recession, there is now increased monitoring of global debt positions. There are now regular central banks' reviews of financial stability, the BIS has invested in creating a database of debt across countries and the EU has established an early warning system by introducing the Macroeconomic Imbalance Procedure (MIP). In recent work the IMF (2018) has established a 'growth at risk' framework which aims to provide a quantitative assessment of the degree to which future GDP growth faces downside risks from financial vulnerabilities. It suggested that, looking three years ahead, "risks to medium-term growth stemming from the current easy financial conditions are well above historical norms".

By themselves, these and similar activities will not prevent or solve any problems that may arise from a combination

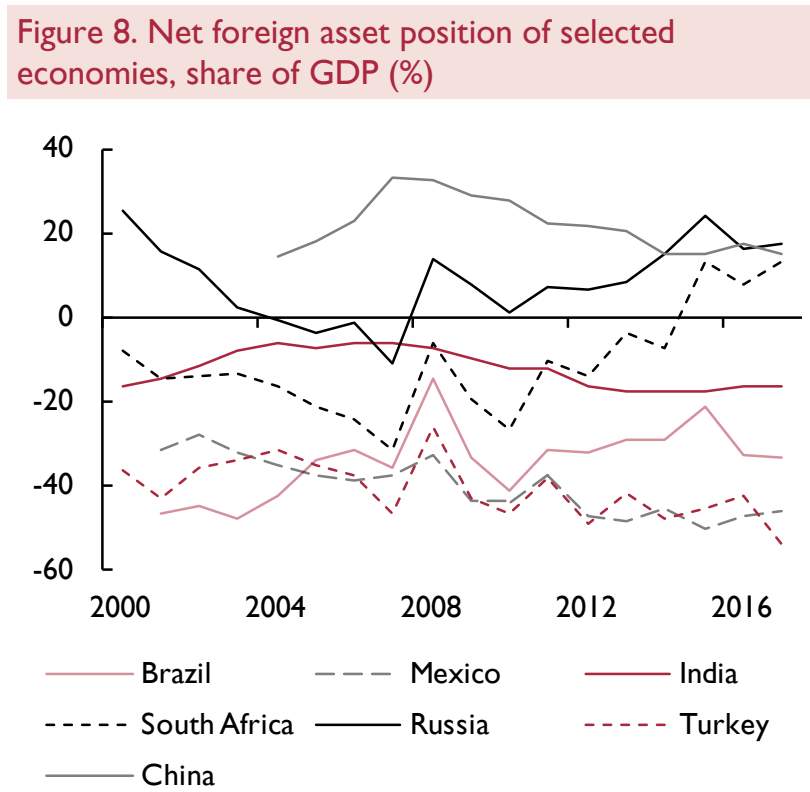

Source: IMF WEO database. 
of high levels of indebtedness and adverse economic shocks. But they indicate an increased awareness of the need for monitoring and might act as early warning indicators, particularly of some global concerns.

It is important not only to monitor debt levels and to try to identify any systemic risks from the pattern of increased indebtedness but also to monitor possible mitigating factors. There is a lot of focus on debt, but seemingly less so on asset levels. One outcome from the East Asia crisis was that the affected countries subsequently built up their foreign reserves. These were viewed as providing an initial buffer in the event of such a sequence of adverse effects, particularly the largely unanticipated spillover effects across the region as occurred in 1997-8, being repeated. A country's net foreign asset position is now seen as an important measure of a sovereign borrower's strength (Lane and Milesi-Ferretti, 2007). While the relatively benign international financial conditions of recent years have enabled a number of emerging market economies to take steps to address imbalances and build buffers, the expansion of debt has run counter to this. In some emerging market economies, such as Turkey and Mexico (as shown in figure 8), possible potential vulnerabilities have grown.

Ultimately, overall debt levels are not the only issue that need to be considered - issues such as the diversification of the sources of debt, the distribution of debt (across companies and households) and the extent and distribution of assets in economies provide a more complete picture. As in the consideration of the net foreign asset position, the role of assets held can provide a possible mitigating factor should adverse debt shocks occur. But the rise in debt, and in particular the rise in government debt in advanced economies and in non-financial companies' debt in emerging economies, over the decade since the financial crisis has created new potential risks and vulnerabilities for the global economy. This could especially be the case if the coming years are to see a reduction in monetary policy accommodation in the advanced economies which could affect those borrowers who are rolling over substantial funding. For policy makers with concerns about the increased level of debt, perhaps the real risks will lie, however, with the 'unknown unknowns'. ${ }^{6}$

\section{NOTES}

I The Advanced Economies grouping in the BIS statistics is defined as Australia, Canada, Denmark, the Euro Area, Japan, New Zealand, Norway, Sweden, Switzerland, the United Kingdom and the United States.

2 Total debt is the sum of Government, Household and NonFinancial Corporation debt.
3 BIS defines emerging economies as a group of 21 countries.

4 Reinhart and Rogoff (2010) note, "[W] hereas the link between growth and debt seems relatively weak at 'normal' debt levels, median growth rates for countries with public debt roughly over 90 per cent of GDP are about one per cent lower than otherwise.....surprisingly, the relationship between public debt and growth is remarkably similar across emerging markets and advanced economies.... This is not the case for inflation...By contrast, in emerging market countries, high public debt levels coincide with higher inflation."

5 See articles on housing in the research section of this issue.

6 To borrow a phrase from Donald Rumsfeld, quoted on 12 February 2002. He noted that "if one looks throughout the history of our country and other free countries, it is the latter category [unknown unknowns] that tend to be the difficult ones."

\section{REFERENCES}

Aghevli, B.B. (1999), 'The Asian crisis: causes and remedies', Finance and Development, June.

Bank of England (2018), Financial Stability Report, June.

Bean, C., Broda, C., Ito, T. and Kroszner, R. (20I5), 'Low for long? Causes and consequences of persistently low interest rates', Geneva Reports on the World Economy, I7, CEPR Press.

Cohen, D. and Valadier, C. (20II), 'The sovereign debt crisis that was not', in Braga, C.A.P. and Vincelette, G.A. (eds), Sovereign Debt and the Financial Crisis, Washington: The World Bank.

Collard, F., Habib, M. and Rochet, J.-C. (20I5), 'Sovereign debt sustainability in advanced economies', Journal of the European Economic Association, June.

DeLong, J.B. (20I3), 'Risks of debt: the real flaw in Reinhart-Rogoff?' available at https://www.project-syndicate.org/blog/risks-of-debt-the-real-flaw-in-reinhart-rogoff.

Dembiermont, C., Drehmann, M. and Muksatunratana, S. (20I3), 'How much does the private sector really borrow?', BIS Quarterly Review, March.

Herndon, T., Ash, M. and Pollin, R. (20I3), 'Does high public debt consistently stifle economic growth? A critique of Reinhart and Rogoff, Political Economy Research Institute, University of Massachusetts Amherst, Working Paper, April.

Holston, K., Laubach, T. and Williams, J.C. (20I6), 'Measuring the natural rate of interest: international trends and determinants', Federal Reserve Bank of San Francisco Working Paper, 2016-II, December.

International Monetary Fund (20I5), 'Corporate leverage in emerging markets - a concern?', IMF Global Outlook, October.

-(20I8), Global Financial Stability Report, May.

King, M. (20I2), Speech to the South Wales Chamber of Commerce, Cardiff, October.

Lane, P.R. and Milesi-Ferretti, G.M. (2007), 'The external wealth of nations mark II: Revised and extended estimates of foreign assets and liabilities, 1970-2004', Journal of International Economics, November.

McKinsey \& Company, (2018), 'Rising corporate debt: peril or promise?', McKinsey Global Institute Discussion Paper, June.

Mian, A. and Sufi, A. (2014), House of Debt: How They (and You) Caused the Great Recession and How We Can Prevent it from Happening Again, University of Chicago Press.

Mishkin, F. (20I I), 'How should central banks respond to asset-price bubbles? The 'lean' versus 'clean' debate after the GFC', Reserve Bank of Australia Bulletin, June.

Naisbitt, B. (2018), 'The re-emergence of concerns about debt', National Institute Economic Review, May.

Reinhart, C. and Rogoff, K. (20I0), 'Growth in a time of debt', American Economic Review, May. 